\title{
Electrochemical Technologies for the Treatment of Pesticides
}

2

$$
\begin{gathered}
\text { Clément Trellu }^{1} \text {, Hugo Olvera Vargas }{ }^{2},{\text { Emmanuel } \text { Mousset }^{3}, \text { Nihal Oturan }^{1} \text {, }}_{\text {Mehmet A. Oturan }}^{1, *}
\end{gathered}
$$

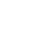

\footnotetext{
${ }^{1}$ Université Gustave Eiffel, Laboratoire Géomatériaux et Environnement EA 4508,
} 77454 Marne-la-Vallée, Cedex 2, France

${ }^{2}$ Instituto de Energías Renovables, Universidad Nacional Autónoma de México (IERUNAM), Priv. Xochicalco S/N, Col. Centro, 62580, Temixco, Morelos, México

${ }^{3}$ Laboratoire Réactions et Génie des Procédés, Université de Lorraine, CNRS, LRGP, 1 F-54000 Nancy, France

* Corresponding author's Email: Mehmet.oturan@univ-eiffel.fr (Mehmet A. Oturan) 4

\section{SI "Electrochemical Technologies for Wastewater Treatment" in}

\section{Current Opinion in Electrochemistry}

\section{Abstract}

Pesticides are worldwide used in large amount to increase yield in agriculture. On the 2 other hand, they are in general toxic/persistent organic pollutants presenting strong 3 adverse effects to the environment and human health, including acute and chronic toxicity. 4 Consequently, water polluted by pesticides should be treated efficiently before its release 5 into receiving water bodies to protect natural aquatic environment. Different methods 6 have been used for treatment of water contaminated by pesticides. Among them, 7 electrochemical technology seems to be very efficient to remove pesticides from water. 8 Therefore this review aims to provide an overview of the recent works on the treatment 29 of pesticide wastewater using electrochemical technology with a special focus on 
electrochemical advanced oxidation processes which demonstrated high efficiency in removal of various type of pesticides from contaminated water.

\section{Keywords:}

34 Electro-Fenton; Pesticide; Electro-oxidation; Organic pollutants; Hydroxyl radicals, 35 Wastewater treatment

\section{Introduction}

The term pesticides cover a large variety of molecules used for improving agricultural productivity. With more than 4 million tons applied worldwide annually, they are among the most widespread xenobiotics released by anthropogenic activities [1]. It has been demonstrated that several pesticides present strong adverse effects on ecosystems (alteration of the biodiversity) and human health, including acute toxicity (accidental deaths by poisoning, particularly in developing countries) and chronic toxicity (even when exposed at low concentrations), as reported, in the case of India for example [2]. After being used on agricultural crops, pesticides reach soil, air and water bodies where their accumulation depends on their persistence and can reach significant concentrations in the different environmental compartments [1]. Regulatory authorities are trying to take into consideration this environmental issue by introducing standards for pesticide content in drinking water (e.g., in the European Union, $100 \mathrm{ng} \mathrm{L}^{-1}$ for individual pesticides and $500 \mathrm{ng} \mathrm{L}^{-1}$ for the sum of all pesticides detected [3]). Therefore, the removal of pesticides is currently an important challenge for environmental engineers working on soil remediation and water treatment, including drinking water, municipal wastewater and some industrial wastewaters. The development of electrochemical processes might help

54 to address this issue [4*]. While electrocoagulation process is able to separate some of 55 pesticides, electrochemical advanced oxidation processes (EAOPs) are widely recognized 56 for their capacity to remove efficiently and in a non-selective way a very large range of pesticides from water [5]. EAOPs can also be applied for the pesticides removal from groundwater and from soil after a soil washing step [6**]. The objective of this review is to provide a concise overview of the recent reports, including the advantages and

60 drawbacks of electrochemical processes for treating pesticides and to provide new 61 insights on the future of these technologies in this area. 


\section{Which electrochemical technologies are used for treating pesticides?}

64 Different electrochemical technologies were applied to the treatment of pesticides in water and soils. The two EAOPs (electro-Fenton (EF) and electrooxidation (or anodic oxidation (AO)) are the most widely used processes for treatment of pesticides. Electrooxidation is based on generation of hydroxyl radicals $\left({ }^{\circ} \mathrm{OH}\right)$ from electrooxidation of water at the anode surface when using a non-active anode like $\mathrm{BDD}$ or $\mathrm{PbO}_{2}$. These radicals are physisorbed on anode surface and constitute strongest oxidant species at the vicinity of the electrode [7]. Therefore, oxidation of pollutants requires their transfer to the surface of anode where they are oxidized/mineralized by ${ }^{\circ} \mathrm{OH}$. Several recent works have demonstrated high efficiency of this process, alone [8-10] or in combination with other technologies $[11,12]$ for the treatment of synthetic or real pesticides wastewater. In contrast, in $\mathrm{EF},{ }^{\circ} \mathrm{OH}$ are homogeneously generated in the bulk solution from the reaction between electrochemically formed $\mathrm{H}_{2} \mathrm{O}_{2}$ and a catalyst (generally $\mathrm{Fe}^{2+}$ ion) to remove pesticides from water $[13,14]$. To enhance process efficiency, EF has been coupled to other methods such as photocatalysis [15] and solar photocatalysis [16]. Electrocoagulation [17,18] and electrokinetics [19] were also applied to water treatment and soil remediation, respectively.

\section{Applications for the treatment of pesticides in water}

Several kinds of electrochemical processes have been successfully applied to treat a number of pesticides in water including EF and its photo-assisted versions (photoelectroFenton (PEF) and solar photoelectro-Fenton (SPEF)), direct or $\mathrm{Cl}^{-}$mediated anodic oxidation (AO), electrocoagulation (EC) and photoelectrocatalysis (PEC) (Table 1). In general, fast degradation kinetics have been observed, with complete removal of target pesticides ranging from few minutes to few hours depending on the process and experimental conditions used. Besides, high mineralization yields $(>50 \%$ of TOC removal) are generally achieved within few hours of treatment. It is worthy to note that EF and its photo-assisted variants (PEF and SPEF), along with AO using BDD anodes have shown the fastest degradation kinetics and the highest mineralization yields (almost total TOC removal in few hours) $\left[9^{*}, 20-23^{*}\right]$, which is attributed to the efficient 
93 formation of strong oxidants: homogeneous ${ }^{\circ} \mathrm{OH}(\mathrm{EF})$ and heterogeneous $\mathrm{BDD}\left({ }^{\circ} \mathrm{OH}\right)(\mathrm{AO}$

94 and EF with BDD anode) during the process.

95 The use of accessible carbonaceous cathode materials (i.e., carbon felt, carbon cloth, 96 carbon fibers, etc.) constitutes a technical advantage of EF and makes the process 97 economically attractive. In contrast, BDD is still a costly material restraining the application of AO at large-scale [24,25*].

99 Different pesticides have been used as model pollutants to evaluate the performance of 100 new electrode materials. For example, an $\mathrm{N}$-doped graphene cathode for $\mathrm{H}_{2} \mathrm{O}_{2}$ production 101 and its activation was successfully tested for the degradation of 2,4102 dichlorophenoxyacetic acid [26], while a dual anode consisting of one layer of $\mathrm{SnO}_{2}$ $103 \mathrm{Sb}_{2} \mathrm{O}_{3} / \mathrm{PbO}_{2}$, and one of $\mathrm{TiO}_{2}$ deposited on the opposite sides of a Ti plate was used to 104 treat the herbicide fenuron by photocatalytically assisted AO [27]. The development of 105 high-surface-area and durable electrode materials is an active research field with great 106 improvement opportunities.

107 On the other hand, most of the investigations have been conducted using aqueous 108 solutions of the target compounds (some of them using commercial formulations) to 109 obtain important information about the kinetics, mechanisms, and optimal experimental 110 conditions for the degradation/mineralization of such pollutants. However, the effect of 111 the matrix in real wastewaters is not considered in such works. Hence, more 112 investigations using real water sources contaminated by pesticides are highly 113 recommended in order to evaluate the influence of the matrix (additives, other organics 114 as well as inorganic compounds) on the process performance [25*]. In this sense, the 115 presence of radical scavengers may significantly affect the degradation/mineralization 116 efficiency. Additionally, the concentrations of target pollutants in synthetic solutions are 117 generally orders of magnitude higher than the concentrations in real water sources [28], 118 which may affect the efficiencies under real scenarios, especially considering the mass 119 transport limitations to the electrode surface inherent to electrochemical processes.

120 Another important point to keep in mind is that most studies on electrochemical treatment 121 of pesticides have been carried out in small laboratory-scale devices with capacities rarely 122 exceeding $1 \mathrm{~L}$. With this respect, the design of electrochemical reactors with the capacity 123 to treat greater volumes is fundamental for the application of such treatment methods at 124 industrial scale. Larger-scale systems would give a more reliable assessment of both 
125 investment and operating costs of electrochemical processes (operating costs tightly

126 related to electrical energy consumption).

\section{4. Applications for the treatment of pesticides in soil}

129 Diffuse pollution of soils is a very complex environmental issue because of the huge 130 amount of soils that might be concerned for remediation and the great complexity of 131 treating contaminated soils. Electrochemical technologies cannot be considered as 132 sustainable solutions in such case. However, manufacturing and handling of pesticides 133 can lead to accidental release and create a localized acute contamination, for which the 134 application of electrochemical technologies might be suitable.

135 First, electrokinetic processes based on the application of an electric field in the soil 136 present the great interest to avoid the use of any chemical compounds and to be applied 137 in situ. It has been reported at lab-scale that it is possible to recover pollutants in catholyte 138 and anolyte wells by dragging with the electroosmotic flux or by electromigration of ionic 139 compounds [19]. However, it has been highlighted that the influence of these mechanisms 140 is very low when applying this process at pilot scale [19]. As high current intensities have 141 to be applied, the controlling mechanism becomes the electric heating of the soil, which 142 influences pollutant volatilization from soil. Current studies focus mainly on the 143 combination with other processes (e.g., phytoremediation or the use of additives such as 144 oxidants) $\left[33^{*}, 34\right]$ or by implementing efficiently this technology at pilot-scale 145 (optimization of powering control, inversion of electrode polarity, etc.) [33*,34].

146 Secondly, a treatment strategy involving an electrochemical process as post-treatment 147 step can be applied for treating soil washing solutions [6**]. Soil washing (as first step) 148 aims at transferring pesticides from the soil-sorbed fraction to the aqueous phase. 149 Extracting agents (cyclodextrins or surfactants such as Tween 80, Triton X 100 or sodium 150 dodecyl sulfate) can be used for improving the transfer of hydrophobic pesticides. The 151 soil washing solution is therefore a complex mixture of all compounds that can be 152 mobilized, including target pesticides, soil organic matter, inorganic species, fine 153 particles and extracting agents [6**]. Several studies have reported that EAOPs are able

154 to remove the organic load of these effluents [36,37*]. Recent studies are reported in 155 Table 2 . The possibility of combination with a biological treatment has also been assessed 
156 for improving the cost-effectiveness [38,39] and few studies focused on selective electro-

157 oxidation of target pollutants in order to be able to reuse extracting agents [39**,40*].

158 However, further studies are required in order to scale up such treatment for field scale 159 applications and for assessing the sustainability of this approach.

\section{5. Challenges for full-scale applications}

162 There are several challenges for upscaling the electrochemical technologies regarding the

163 removal of pesticides, especially about the reactor design.

164 When the option consists to treat pesticides from urban wastewater or natural water, their 165 concentrations in solution is very low (from $\mathrm{ng} \mathrm{\textrm {L } ^ { - 1 }}$ to $\mu \mathrm{g} \mathrm{L}^{-1}$ ) [4*]. It means that it is

166 required to strongly favor the contact between the pollutant and the electrodes in $\mathrm{AO}$ 167 and/or to enhance the promotion of the homogeneous oxidation with EF process [45]. 168 This will enhance the faradaic yield, while keeping high pesticides removal yields. 169 Moreover, these effluents have generally a low electric conductivity [4*], which means 170 that the reactor design need to be also adapted in order to avoid adding a supporting 171 electrolyte. Microfluidic thin film electrochemical reactors have emerged as a possible 172 response towards these issues by intensifying the transport of species and reducing the 173 ohmic resistance [46-48]). Further studies are needed at large scale in order to validate 174 the lab-scale systems.

175 When the pesticides are solubilized in soil washing/flushing effluent, their concentrations 176 in solution can be increased to $\mathrm{mg} \mathrm{L}^{-1}$ range [28]. Still, the faradaic yield remains low, 177 because the extracting agent represents the main organic source. To make it economically 178 viable at larger scale, the recovery of extracting agent has to be considered while the 179 selective removal of the contaminants should be effective. Combined treatments in hybrid 180 or sequenced reactor(s) required supplementary proofs at high technology readiness 181 levels.

182 In electrokinetics systems, lab-scale experiments could not predict well the pilot and 183 larger scale applications [33*]. The difficulties remain in the ability to have geometrical 184 and operational similarity between the setups [33*], which makes changing the 185 distribution of parameters $(\mathrm{pH}$, conductivity, temperature, pollutants and ions 186 concentrations) and the mechanisms involved [19,49]. Furthermore, the soil 
187 characteristics (electric conductivity, granulometry, age of pollution,...) vary a lot from 188 one sample to another, which makes difficult the extrapolation of the results for upscaling 189 studies. Additional large scales studies need to be performed in a comparable way by 190 implementing dimensional analysis.

191

\section{6. Conclusions and future perspectives}

193 Electrochemical processes stand out as promising technologies for the treatment of 194 harmful organic pollutants (pesticides, synthetic dyes, pharmaceutical residues,...) in 195 contaminated water and soils. Particularly, EAOPs present great advantages due to their 196 capacity to remove, in a non-selective way, a large range of pesticides, which can be 197 degraded and even fully mineralized in order to avoid the presence of toxic by-products 198 remaining in the treated solution. Besides application to contaminated water, they can 199 also be employed for the removal of pesticides in soil washing effluents. The next 200 challenge for further development of electrochemical technology and particularly of 201 EAOPs is clearly related to full-scale applications, including the design of suitable 202 reactors and the application to real effluents. This step is required in order to conclude on 203 the sustainability and cost-effectiveness of these processes. 


\section{References:}

[1] F. Maggi, F.H.M. Tang, D. la Cecilia, A. McBratney, PEST-CHEMGRIDS, global gridded maps of the top 20 crop-specific pesticide application rates from 2015 to 2025, Sci. Data. 6 (2019) 1-20. doi:10.1038/s41597-019-0169-4.

[2] P.C. Abhilash, N. Singh, Pesticide use and application: An Indian scenario, J. Hazard. Mater. 165 (2009) 1-12. doi:10.1016/j.jhazmat.2008.10.061.

[3] European Commission, Synthesis report on the quality of drinking water in the union examining member states' reports for the 2011-2013 period, foreseen under Article 13(5) of Directive 98/83/EC, Brussels, Belgium, 2016.

[4] M.A. Rodrigo, N. Oturan, M.A. Oturan, Electrochemically assisted remediation of pesticides in soils and water: A review, Chem. Rev. 114 (2014) 8720-8745. doi:10.1021/cr500077e.

This is an extensive and critical review article on electrochemical technology applied to treatment of water and soils contaminated by pesticides.

[5] C.A. Martínez-Huitle, M.A. Rodrigo, I. Sirés, O. Scialdone, Single and coupled electrochemical processes and reactors for the abatement of organic water pollutants: a critical review., Chem. Rev. 115 (2015) 13362-407. doi:10.1021/acs.chemrev.5b00361.

[6] C. Trellu, E. Mousset, Y. Pechaud, D. Huguenot, E.D. van Hullebusch, G. Esposito, et al., Removal of hydrophobic organic pollutants from soil washing/flushing solutions: A critical review, J. Hazard. Mater. 306 (2016) 149-174.

doi:10.1016/j.jhazmat.2015.12.008.

This review throughly summerises the feasibility and critical choices during treatment of soils contaminated hydrophobic organic pollutants with different methods combined with washing/flashing technics

[7] P. V. Nidheesh, G. Divyapriya, N. Oturan, C. Trellu, M.A. Oturan, Environmental applications of boron - doped diamond electrodes: 1. applications in water and wastewater treatment, ChemElectroChem. 6 (2019) 2124-2142. doi:10.1002/celc.201801876.

[8] G.O.S. Santos, K.I.B. Eguiluz, G.R. Salazar-Banda, C. Saez, M.A. Rodrigo, Biodegradability improvement of clopyralid wastes through electrolysis using different 
diamond anodes, Environ. Res. 188 (2020) 109747. doi:10.1016/j.envres.2020.109747.

[9] C.M. Dominguez, N. Oturan, A. Romero, A. Santos, M.A. Oturan, Lindane degradation by electrooxidation process: Effect of electrode materials on oxidation and mineralization kinetics, Water Res. 135 (2018) 220-230.

doi:10.1016/J.WATRES.2018.02.037.

This work reports the treatment of a real wastewater from a lindane production site using electrochemica technology hihhlighting the role of electrode material on process efficiency

[10] J. Cai, M. Zhou, X. Du, X. Xu, Enhanced mechanism of 2,4-dichlorophenoxyacetic acid degradation by electrochemical activation of persulfate on Blue-TiO2 nanotubes anode, Sep. Purif. Technol. 254 (2021) 117560. doi:10.1016/j.seppur.2020.117560.

[11] A. Raschitor, J. Llanos, M.A. Rodrigo, P. Cañizares, Combined electrochemical processes for the efficient degradation of non-polar organochlorine pesticides, J. Environ. Manage. 248 (2019) 109289. doi:10.1016/j.jenvman.2019.109289.

[12] N.L. Pedersen, M. Nikbakht Fini, P.K. Molnar, J. Muff, Synergy of combined adsorption and electrochemical degradation of aqueous organics by granular activated carbon particulate electrodes, Sep. Purif. Technol. 208 (2019) 51-58. doi:10.1016/j.seppur.2018.05.023.

[13] N. Oturan, M.A. Oturan, Electro-Fenton process: Background, new developments, and applications, in: Electrochem. Water Wastewater Treat., Elsevier, 2018: pp. 193-221. doi:10.1016/B978-0-12-813160-2.00008-0.

[14] M. Zhou, M.A. Oturan, I. Sirés, Electro-Fenton process : new trends and scale-up, in: Handb. Environ. Chem., Springer Singapore, 2018: p. 430.

[15] D.R.V. Guelfi, E. Brillas, F. Gozzi, A. Machulek, S.C. de Oliveira, I. Sirés, Influence of electrolysis conditions on the treatment of herbicide bentazon using artificial UVA radiation and sunlight. Identification of oxidation products, J. Environ. Manage. 231 (2019) 213-221. doi:10.1016/j.jenvman.2018.10.029.

[16] F. Gozzi, I. Sirés, A. Thiam, S.C. de Oliveira, A.M. Junior, E. Brillas, Treatment of single and mixed pesticide formulations by solar photoelectro-Fenton using a flow plant, Chem. Eng. J. 310 (2017) 503-513. doi:10.1016/j.cej.2016.02.026.

[17] S. Garcia-Segura, M.M.S.G. Eiband, J.V. de Melo, C.A. Martínez-Huitle, Electrocoagulation and advanced electrocoagulation processes: A general review about 
the fundamentals, emerging applications and its association with other technologies, J. Electroanal. Chem. 801 (2017) 267-299. doi:10.1016/J.JELECHEM.2017.07.047.

[18] M. Muñoz, J. Llanos, A. Raschitor, P. Cañizares, M.A. Rodrigo, Electrocoagulation as the Key for an Efficient Concentration and Removal of Oxyfluorfen from Liquid Wastes, Ind. Eng. Chem. Res. 56 (2017) 3091-3097. doi:10.1021/acs.iecr.7b00347.

[19] R. López-Vizcaíno, C. Risco, J. Isidro, S. Rodrigo, C. Saez, P. Cañizares, et al., Scaleup of the electrokinetic fence technology for the removal of pesticides. Part II: Does size matter for removal of herbicides?, Chemosphere. 166 (2017) 549-555. doi:10.1016/j.chemosphere.2016.09.114.

[20] H. Zazou, N. Oturan, M. Sönmez Çelebi, M. Hamdani, M.A. Oturan, Cold incineration of 1,2-dichlorobenzene in aqueous solution by electrochemical advanced oxidation using DSA/Carbon felt, Pt/Carbon felt and BDD/Carbon felt cells, Sep. Purif. Technol. 208 (2019) 184-193. doi:10.1016/J.SEPPUR.2018.03.030.

[21] A. Thiam, I. Sirés, R. Salazar, E. Brillas, On the performance of electrocatalytic anodes for photoelectro-Fenton treatment of synthetic solutions and real water spiked with the herbicide chloramben, J. Environ. Manage. 224 (2018) 340-349. doi:10.1016/j.jenvman.2018.07.065.

[22] P.A. Diaw, N. Oturan, M.D. Gaye Seye, O.M.A. Mbaye, M. Mbaye, A. Coly, et al., Removal of the herbicide monolinuron from waters by the electro-Fenton treatment, J. Electroanal. Chem. 864 (2020) 114087. doi:10.1016/j.jelechem.2020.114087.

[23] E. Brillas, A review on the photoelectro-Fenton process as efficient electrochemical advanced oxidation for wastewater remediation. Treatment with UV light, sunlight, and coupling with conventional and other photo-assisted advanced technologies, Chemosphere 250 (2020) 126198. doi: 10.1016/j.chemosphere.2020.126198

This detailled and comprehensive review throughly summerises the different techniques combinng the electro-Fenton process with different photochemical processes for water/wastwater treatment.

[24] J. Radjenovic, D.L. Sedlak, Challenges and opportunities for electrochemical processes as next-generation technologies for the treatment of contaminated water, Environ. Sci. Technol. 49 (2015) 11292-11302. doi:10.1021/acs.est.5b02414.

[25] H. Olvera-Vargas, N. Gore-Datar, O. Garcia-Rodriguez, S. Mutnuri, O. Lefebvre, Electro-Fenton treatment of real pharmaceutical wastewater paired with a BDD anode: 
Reaction mechanisms and respective contribution of homogeneous and heterogenous OH, Chem. Eng. J. 404 (2021) 126524. doi:10.1016/j.cej.2020.126524.

This study underlines the simultaneous production of homogeneous (electro-Fenton) and heterogeneous (anodic oxidation) hydroxyl radicals when using BDD anode in electro-fenton process.

[26] W. Yang, M. Zhou, N. Oturan, Y. Li, P. Su, M.A. Oturan, Enhanced activation of hydrogen peroxide using nitrogen doped graphene for effective removal of herbicide 2,4-D from water by iron-free electrochemical advanced oxidation, Electrochim. Acta. 297 (2019) 582-592. doi:10.1016/j.electacta.2018.11.196.

[27] K. Barbari, R. Delimi, Z. Benredjem, S. Saaidia, A. Djemel, T. Chouchane, et al., Photocatalytically-assisted electrooxidation of herbicide fenuron using a new bifunctional electrode $\mathrm{PbO} 2 / \mathrm{SnO} 2-\mathrm{Sb} 2 \mathrm{O} 3 / \mathrm{Ti} / / \mathrm{Ti} / \mathrm{TiO} 2$, Chemosphere. 203 (2018) 110. doi:10.1016/j.chemosphere.2018.03.126.

[28] S. Garcia-Segura, A.B. Nienhauser, A.S. Fajardo, R. Bansal, C.L. Coonrod, J.D. Fortner, et al., Disparities between experimental and environmental conditions: Research steps toward making electrochemical water treatment a reality, Curr. Opin. Electrochem. 22 (2020) 9-16. doi:10.1016/j.coelec.2020.03.001.

[29] R. Oriol, M. del P. Bernícola, E. Brillas, P.L. Cabot, I. Sirés, Paired electro-oxidation of insecticide imidacloprid and electrodenitrification in simulated and real water matrices, Electrochim. Acta. 317 (2019) 753-765. doi:10.1016/j.electacta.2019.05.002.

[30] X. Xu, J. Cai, M. Zhou, X. Du, Y. Zhang, Photoelectrochemical degradation of 2,4dichlorophenoxyacetic acid using electrochemically self-doped Blue TiO2 nanotube arrays with formic acid as electrolyte, J. Hazard. Mater. 382 (2020) 121096. doi:10.1016/j.jhazmat.2019.121096.

[31] J.E.L. Santos, M.A. Gómez, D.C.-D. Moura, M. Cerro-López, M.A. Quiroz, C.A. Martínez-Huitle, Removal of herbicide 1-chloro-2,4-dinitrobenzene (DNCB) from aqueous solutions by electrochemical oxidation using boron-doped diamond (BDD) and $\mathrm{PbO} 2$ electrodes, J. Hazard. Mater. (2020) 123850. doi:10.1016/j.jhazmat.2020.123850.

[32] N.S. Lima, É.M. Souza, N.H. Torres, R. Bergamasco, M.N. Marques, S. GarciaSegura, et al., Relevance of adjuvants and additives of pesticide commercial 
formulation on the removal performance of glyphosate by electrochemically driven processes, J. Clean. Prod. 212 (2019) 837-846. doi:10.1016/j.jclepro.2018.12.007.

[33] V. Sánchez, F.J. López-Bellido, P. Cañizares, J. Villaseñor, L. Rodríguez, Scaling up the electrokinetic-assisted phytoremediation of atrazine-polluted soils using reversal of electrode polarity: A mesocosm study, J. Environ. Manage. 255 (2020) 109806. doi:10.1016/j.jenvman.2019.109806.

This reference brings interesting key issues regarding the scaling up studies in electrokinetic process, especially when combined with phytoremediation

[34] L. Ren, H. Lu, L. He, Y. Zhang, Enhanced electrokinetic technologies with oxidization-reduction for organically-contaminated soil remediation, Chem. Eng. J. 247 (2014) 111-124. doi:10.1016/j.cej.2014.02.107.

[35] M. Millán, P.Y. Bucio-Rodríguez, J. Lobato, C.M. Fernández-Marchante, G. RoaMorales, C. Barrera-Díaz, et al., Strategies for powering electrokinetic soil remediation: A way to optimize performance of the environmental technology, J. Environ. Manage. 267 (2020) 110665. doi:10.1016/j.jenvman.2020.110665.

[36] E.V. dos Santos, C. Sáez, C.A. Martínez-Huitle, P. Cañizares, M.A. Rodrigo, Combined soil washing and CDEO for the removal of atrazine from soils, J. Hazard. Mater. 300 (2015) 129-134. doi:10.1016/j.jhazmat.2015.06.064.

[37] E.V. Dos Santos, C. Sáez, C.A. Martínez-Huitle, P. Cañizares, M.A. Rodrigo, The role of particle size on the conductive diamond electrochemical oxidation of soil-washing effluent polluted with atrazine, Electrochem. Commun. 55 (2015) 26-29. doi:10.1016/j.elecom.2015.03.003.

This work describes the role of particle size during treatment of soil washing solutions during electrooxidation with BDD anode.

[38] E. Mousset, N. Oturan, E.D. van Hullebusch, G. Guibaud, G. Esposito, M.A. Oturan, Treatment of synthetic soil washing solutions containing phenanthrene and cyclodextrin by electro-oxidation. Influence of anode materials on toxicity removal and biodegradability enhancement, Appl. Catal. B Environ. 160-161 (2014) 666-675. doi:http://dx.doi.org/10.1016/j.apcatb.2014.06.018.

[39] C. Trellu, O. Ganzenko, S. Papirio, Y. Pechaud, N. Oturan, D. Huguenot, et al., Combination of anodic oxidation and biological treatment for the removal of phenanthrene and Tween 80 from soil washing solution, Chem. Eng. J. 306 (2016) 
588-596. doi:10.1016/j.cej.2016.07.108.

[40] C. Trellu, N. Oturan, Y. Pechaud, E.D. van Hullebusch, G. Esposito, M.A. Oturan, Anodic oxidation of surfactants and organic compounds entrapped in micelles Selective degradation mechanisms and soil washing solution reuse, Water Res. 118 (2017) 1-11. doi:10.1016/J.WATRES.2017.04.013.

This study underlines selectuive oxidation mechanisms during anodic oxidation in order to revover and reuse of surfactants used during washing/flashing processes.

[41] C. Trellu, Y. Pechaud, N. Oturan, E. Mousset, E.D. van Hullebusch, D. Huguenot, et al., Remediation of soils contaminated by hydrophobic organic compounds: How to recover extracting agents from soil washing solutions?, J. Hazard. Mater. (2020) 124137. doi:10.1016/j.jhazmat.2020.124137.

This critical review throughly summerises different techniques used in remediation of soils and possibilities for recovering extracting agents used during washing step for cost effictiveness of treating soil washing solutions.

[42] E. Vieira Dos Santos, C. Sáez, P. Cañizares, C.A. Martínez-Huitle, M.A. Rodrigo, Treating soil-washing fluids polluted with oxyfluorfen by sono-electrolysis with diamond anodes, Ultrason. Sonochem. 34 (2017) 115-122. doi:10.1016/j.ultsonch.2016.05.029.

[43] M. Muñoz-Morales, M. Braojos, C. Sáez, P. Cañizares, M.A. Rodrigo, Remediation of soils polluted with lindane using surfactant-aided soil washing and electrochemical oxidation, J. Hazard. Mater. 339 (2017) 232-238. doi:10.1016/j.jhazmat.2017.06.021.

[44] M.B. Carboneras Contreras, F. Fourcade, A. Assadi, A. Amrane, F.J. FernandezMorales, Electro Fenton removal of clopyralid in soil washing effluents, Chemosphere. 237 (2019) 124447. doi:10.1016/j.chemosphere.2019.124447.

[45] E. Mousset, Y. Pechaud, N. Oturan, M.A. Oturan, Charge transfer/mass transport competition in advanced hybrid electrocatalytic wastewater treatment: Development of a new current efficiency relation, Appl. Catal. B Environ. 240 (2019) 102-111. doi:10.1016/J.APCATB.2018.08.055.

[46] P. Ma, H. Ma, S. Sabatino, A. Galia, O. Scialdone, Electrochemical treatment of real wastewater. Part 1: Effluents with low conductivity, Chem. Eng. J. 336 (2018) 133140. doi:10.1016/j.cej.2017.11.046. 
[47] J.F. Pérez, J. Llanos, C. Sáez, C. López, P. Cañizares, M.A. Rodrigo, Development of an innovative approach for low-impact wastewater treatment: A microfluidic flowthrough electrochemical reactor, Chem. Eng. J. 351 (2018) 766-772. doi:10.1016/j.cej.2018.06.150.

[48] E. Mousset, Unprecedented reactive electro-mixing reactor: Towards synergy between micro- and macro-reactors?, Electrochem. Commun. 118 (2020) 106787. doi:10.1016/j.elecom.2020.106787.

[49] R. López-Vizcaíno, C. Risco, J. Isidro, S. Rodrigo, C. Saez, P. Cañizares, et al., Scaleup of the electrokinetic fence technology for the removal of pesticides. Part I: Some notes about the transport of inorganic species, Chemosphere. 166 (2017) 540-548. doi:10.1016/j.chemosphere.2016.09.113. 
Table 1. Compilation of recent works on the electrochemical treatment of pesticides in water.

\begin{tabular}{|c|c|c|c|c|c|c|}
\hline Pesticide & Process & Cell configuration & $\begin{array}{l}\text { Operating } \\
\text { conditions }\end{array}$ & Removal efficiency & $\begin{array}{l}\text { Energy } \\
\text { consumpt } \\
\text { ion }\end{array}$ & Ref. \\
\hline $\begin{array}{l}\text { 1,2-dichlorobenzene } \\
\left(0.1 \mathrm{mM}=14.7 \mathrm{mg} \mathrm{L}^{-1}\right)\end{array}$ & EF & $\begin{array}{l}\text { Undivided cylindrical cell }(230 \\
\mathrm{mL}), \mathrm{Nb} / \mathrm{BDD} \text { anode }(4 \mathrm{~cm} \mathrm{x} 6 \\
\mathrm{cm}), \text { carbon felt cathode }(16 \mathrm{~cm} \times \\
4 \mathrm{~cm} \times 0.5 \mathrm{~cm}), \text { with constant air } \\
\text { supply }\end{array}$ & $\begin{array}{l}I=500 \mathrm{~mA}, \mathrm{pH}= \\
3, \text { in } \mathrm{Na}_{2} \mathrm{SO}_{4} 0.05 \\
\mathrm{M}, \mathrm{Fe}^{2+}=0.1 \mathrm{mM}\end{array}$ & $\begin{array}{l}\text { Complete degradation in } \\
10 \text { min. } \\
k^{\mathrm{a}}=294.6 \mathrm{~min}^{-1} \\
k_{a b s}{ }^{b}=1.61 \times 10^{9} \mathrm{M}^{-1} \mathrm{~s}^{-1} \\
>90 \% \text { TOC removal }(3 \mathrm{~h})\end{array}$ & $\begin{array}{l}2.5 \mathrm{kWh} \\
(\mathrm{g}-\mathrm{TOC})^{-1}\end{array}$ & {$[20]$} \\
\hline $\begin{array}{l}\text { Chloramben (herbidice) } \\
\left(1.19 \mathrm{mM}=245.1 \mathrm{mg} \mathrm{L}^{-1}\right) \text { spiked } \\
\text { in urban wastewater }\left(\mathrm{TOC}_{0}=15\right. \\
\left.\mathrm{mg} \mathrm{L}^{-1}\right)\end{array}$ & $\mathrm{PEF}^{\mathrm{c}}$ & $\begin{array}{l}\text { Undivided cell }(100 \mathrm{~mL}) \\
\text { Carbon-PTFE } \mathrm{GDE}^{\mathrm{d}} \text { cathode }(3 \\
\left.\mathrm{cm}^{2}\right), \text { BDD anode } \\
\text { UVA lamp }(\lambda=365 \mathrm{~nm})\end{array}$ & $\begin{array}{l}j=33.3 \mathrm{~mA} \mathrm{~cm}{ }^{-2}, \\
\mathrm{pH}=3.4, \text { in } \\
\mathrm{Na}_{2} \mathrm{SO}_{4} 0.05 \mathrm{M}, \\
\mathrm{Fe}^{2+}=0.05 \mathrm{mM}, \\
\mathrm{TOC}_{0}=115 \mathrm{mg} \mathrm{L}^{-1}, \\
\mathrm{~T}=35^{\circ} \mathrm{C}\end{array}$ & $\begin{array}{l}96 \% \text { degradation in } 40 \\
\text { min } \\
k^{\mathrm{a}}=0.13 \mathrm{~min}^{-1} \\
82 \% \text { TOC removal }(3 \mathrm{~h})\end{array}$ & N/A & {$[21]$} \\
\hline $\begin{array}{l}\text { Tebuthiuron }(0.18 \mathrm{mM}=41.1 \mathrm{mg} \\
\left.\mathrm{L}^{-1}\right) \text { and ametryn }(0.09 \mathrm{mM}= \\
\left.20.5 \mathrm{mg} \mathrm{L}^{-1}\right) \text { from commercial } \\
\text { formulations }\end{array}$ & $\mathrm{SPEF}^{\mathrm{e}}$ & $\begin{array}{l}\text { Flow plant with a filter-press cell } \\
\text { and a planar solar photoreactor, } \\
\text { BDD anode }\left(20 \mathrm{~cm}^{2}\right) \text { and carbon- } \\
\text { PTFE GDE cathode }\left(20 \mathrm{~cm}^{2}\right), \mathrm{V} \\
=2.5 \mathrm{~L}\end{array}$ & $\begin{array}{l}j=50 \mathrm{~mA} \mathrm{~cm}^{-2}, \mathrm{pH} \\
=3, \text { in } 0.05 \\
\mathrm{Na}_{2} \mathrm{SO}_{4}, \mathrm{Fe}^{2+}=0.5 \\
\mathrm{mM}, \mathrm{TOC}_{0}=30 \mathrm{mg} \\
\mathrm{L}^{-1}, \text { liquid flow rate } \\
=200 \mathrm{~L} \mathrm{~h}^{-1}\end{array}$ & $\begin{array}{l}\text { Time for complete } \\
\text { degradation: } 240 \mathrm{~min} \text { for } \\
\text { tebuthiuron and } 120 \mathrm{~min} \\
\text { for ametryn. } \\
k_{\text {tebuthiuron }}^{\mathrm{a}}=0.098 \mathrm{~min}^{-1} \\
k_{\text {ametryn }}^{\mathrm{a}}=0.26 \mathrm{~min}^{-1} \\
53 \% \text { TOC removal }(6 \mathrm{~h}\end{array}$ & $\begin{array}{l}2.1 \mathrm{kWh} \\
(\mathrm{g}-\mathrm{TOC})^{-1}\end{array}$ & {$[16]$} \\
\hline $\begin{array}{l}\text { Imidacloprid (insecticide) }(23.7 \\
\left.\mathrm{mg} \mathrm{L}^{-1}\right) \text { in softened natural } \\
\text { groundwater }\end{array}$ & AO-BDD & $\begin{array}{l}\text { Undivided cylindrical cell (150 } \\
\mathrm{mL}), \mathrm{Si} / \mathrm{BDD} \text { anode, Fe cathode } \\
\left.\text { (both } 10 \mathrm{~cm}^{2}\right)\end{array}$ & $\begin{array}{l}\mathrm{j}=5 \mathrm{~mA} \mathrm{~cm}{ }^{-2}, \mathrm{pH} \\
=6.8, \mathrm{TOC}_{0}=10 \\
\mathrm{mg} \mathrm{L}^{-1}, \mathrm{~T}=25^{\circ} \mathrm{C} \\
\mathrm{NO}_{3}^{-}=129.4 \mathrm{mg} \mathrm{L}^{-} \\
1\end{array}$ & $\begin{array}{l}\text { Complete degradation at } \\
210 \text { min. } \\
k^{\mathrm{a}}=0.014 \mathrm{~min}^{-1} \\
61.5 \% \text { TOC removal }(4 \mathrm{~h})\end{array}$ & N/A & [29] \\
\hline
\end{tabular}




\begin{tabular}{|c|c|c|c|c|c|c|}
\hline $\begin{array}{l}\text { Lindane } \\
\left(10 \mathrm{mg} \mathrm{L}^{-1}\right)\end{array}$ & AO-BDD & $\begin{array}{l}\text { Undivided cylindrical cell }(230 \\
\mathrm{mL}), \mathrm{Nb} / \mathrm{BDD} \text { anode }\left(24 \mathrm{~cm}^{2}\right) \\
\text { carbon felt cathode }(18 \mathrm{~cm} \times 5 \\
\mathrm{cm} \times 0.5 \mathrm{~cm})\end{array}$ & $\begin{array}{l}j=8.33 \mathrm{~mA} \mathrm{~cm}^{-2}, \\
\mathrm{pH}=6.5, \text { in } \\
\mathrm{Na}_{2} \mathrm{SO}_{4} 0.05 \mathrm{M}, \\
\mathrm{TOC}_{0}=2.45 \mathrm{mg} \mathrm{L}^{-1}\end{array}$ & $\begin{array}{l}\text { Total removal }(10 \mathrm{~min}) \\
k^{\mathrm{a}}=0.25 \mathrm{~min}^{-1} \\
80 \% \text { TOC removal }(4 \mathrm{~h})\end{array}$ & $\begin{array}{l}15 \mathrm{kWh} \\
(\mathrm{g}-\mathrm{TOC})^{-1}\end{array}$ & {$[9 *]$} \\
\hline $\begin{array}{l}\text { 2,4-dichlorophenoxyacetic acid } \\
\left(20 \mathrm{mg} \mathrm{L}^{-1}\right) \text { (herbicide) }\end{array}$ & $\begin{array}{l}\mathrm{PS}^{\mathrm{f}} \\
\text { activation by } \\
\mathrm{AO}-\mathrm{Blue} \\
\mathrm{TiO}_{2}\end{array}$ & $\begin{array}{l}\text { Undivided cell }(100 \mathrm{~mL}) \text {, Blue } \\
\mathrm{TiO}_{2} \text { anode, } \mathrm{SS} \text { cathode }\end{array}$ & $\begin{array}{l}j=2.5 \mathrm{~mA} \mathrm{~cm}-2, \mathrm{pH} \\
=3.5, \mathrm{PS}=30 \mathrm{mM}\end{array}$ & $\begin{array}{l}\text { Complete degradation in } \\
60 \mathrm{~min} \\
k^{\mathrm{a}}=0.07 \mathrm{~min}^{-1} \\
83 \% \text { TOC removal }(2 \mathrm{~h})\end{array}$ & $\begin{array}{l}0.14 \mathrm{kWh} \\
\mathrm{m}^{-3}\end{array}$ & [10] \\
\hline $\begin{array}{l}\text { Oxyfluorfen } \\
\left(100 \mathrm{mg} \mathrm{L}^{-1}\right) \text { from commercial } \\
\text { formulations (Fluoxil 24 EC) }\end{array}$ & $\mathrm{ECg}$ & $\begin{array}{l}\text { Single-compartment flow cell ( } 5 \\
\text { L-capacity), Fe anode, } \mathrm{SS}^{\mathrm{i}} \\
\text { cathode (both } 100 \mathrm{~cm}^{2} \text { ) }\end{array}$ & $\begin{array}{l}j=5 \mathrm{~mA} \mathrm{~cm}^{-2}, \mathrm{pH} \\
=7, \text { in }_{2} \mathrm{SO}_{4} 0.02 \\
\mathrm{M}, \mathrm{TOC}_{0}=72 \mathrm{mg} \\
\mathrm{L}^{-1}, \mathrm{q}=0.6 \mathrm{~L} \mathrm{~h}^{-1}, \mathrm{Q} \\
=0.836 \mathrm{~A} \mathrm{~h} \mathrm{dm}^{-3}\end{array}$ & $\begin{array}{l}99 \% \text { depletion in } 100 \mathrm{~min} \\
45 \% \text { TOC removal }(1.7 \mathrm{~h})\end{array}$ & N/A & [18] \\
\hline $\begin{array}{l}\text { 2,4-dichlorophenoxyacetic acid } \\
\left(10 \mathrm{mg} \mathrm{L}^{-1}\right)\end{array}$ & Solar PEC & $\begin{array}{l}\text { 3-electrode undivided cell } \\
\text { (quartz), Ti/Blue } \mathrm{TiO}_{2} \\
\text { photoanode }(2.5 \times 2.5 \mathrm{~cm}), \mathrm{SS} \\
\text { cathode }\end{array}$ & $\begin{array}{l}\mathrm{E}=2.4 \mathrm{~V} \text { vs SCE}, \\
\mathrm{pH}=5, \text { in } \mathrm{Na}_{2} \mathrm{SO}_{4} \\
0.05 \mathrm{M} \text {, sunlight } \\
(200 \mathrm{~W} \text { Xenon } \\
\left.\text { lamp, } 80 \mathrm{~mW} \mathrm{~cm}^{-2}\right)\end{array}$ & $\begin{array}{l}\text { Total depletion in } 120 \\
\text { min. } \\
k^{\mathrm{a}}=0.03 \mathrm{~min}^{-1}\end{array}$ & N/A & [30] \\
\hline $\begin{array}{l}\text { 2,4-dichlorophenoxyacetic acid } \\
\left(20 \mathrm{mg} \mathrm{L}^{-1}\right)\end{array}$ & $\begin{array}{l}\mathrm{H}_{2} \mathrm{O}_{2} \text {-based } \\
\text { electrochemi } \\
\text { cal oxidation }\end{array}$ & $\begin{array}{l}\text { 3-electrode undivided cell (150 } \\
\mathrm{mL}), \mathrm{Ti}^{2} \mathrm{RuO}_{2}-\mathrm{IrO}_{2} \text { anode, } \mathrm{N}- \\
\text { doped graphene cathode (both } 3 \\
\mathrm{~cm} \mathrm{x} 4 \mathrm{~cm})\end{array}$ & $\begin{array}{l}\mathrm{E}=4 \mathrm{~V} \text { vs } \mathrm{SCE} \\
\mathrm{pH}=7, \text { in } 0.05 \mathrm{M} \\
\mathrm{Na}_{2} \mathrm{SO}_{4}\end{array}$ & $\begin{array}{l}\text { Total depletion in } 60 \mathrm{~min} \text {. } \\
k^{\mathrm{a}}=0.04 \mathrm{~min}^{-1} \\
88 \% \text { TOC removal }(8 \mathrm{~h})\end{array}$ & & [26] \\
\hline $\begin{array}{l}\text { Monolinuron (herbicide) } \\
\left(0.1 \mathrm{mM}=21.5 \mathrm{mg} \mathrm{L}^{-1}\right)\end{array}$ & EF & $\begin{array}{l}\text { Undivided cylindrical cell ( } 230 \\
\mathrm{~mL}) \text {, BDD anode }\left(24 \mathrm{~cm}^{2}\right), \\
\text { carbon felt cathode, continuous } \\
\text { air supply }\end{array}$ & $\begin{array}{l}I=500 \mathrm{~mA}, \mathrm{pH}=3 \\
\text { in } \mathrm{Na}_{2} \mathrm{SO}_{4} 0.05 \mathrm{M}\end{array}$ & $\begin{array}{l}\text { Complete degradation in } \\
10 \text { min. } \\
k_{a b s}^{\mathrm{b}}=3.1 \times 10^{9} \mathrm{M}^{-1} \mathrm{~s}^{-1} \\
98 \% \text { TOC removal }(8 \mathrm{~h})\end{array}$ & $\begin{array}{l}10 \mathrm{kWh} \\
(\mathrm{g}-\mathrm{TOC})^{-1}\end{array}$ & [22] \\
\hline
\end{tabular}




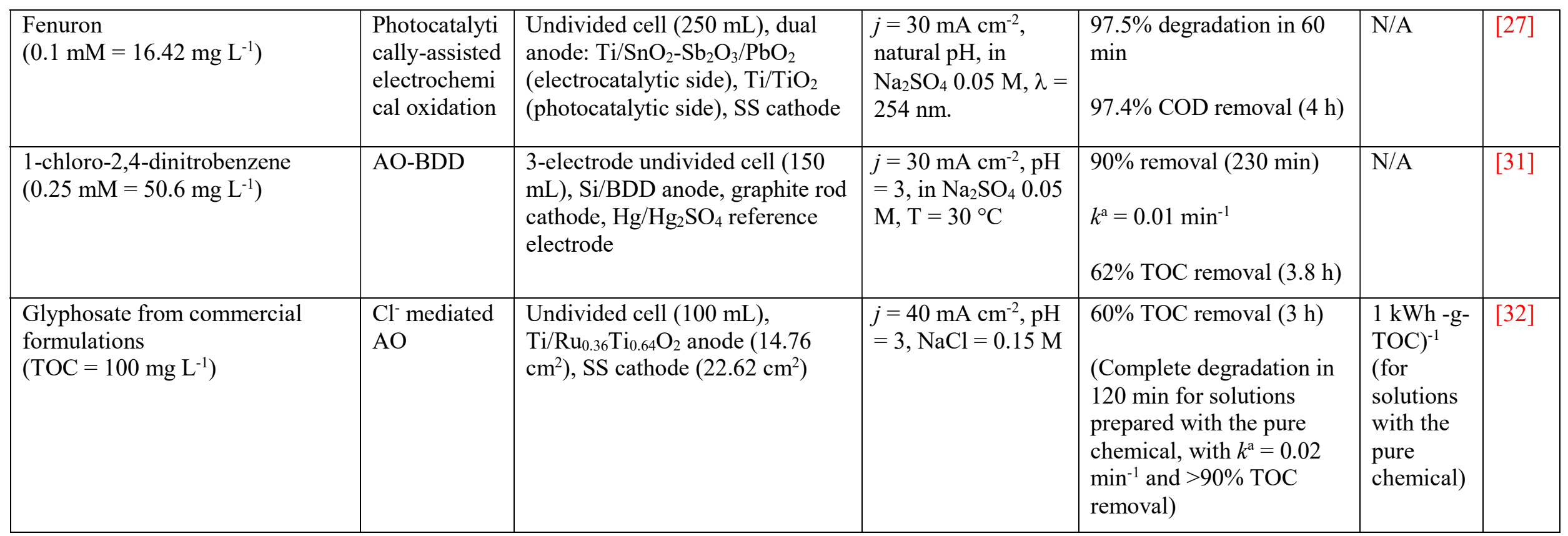

a apparent rate constant of oxidation reaction, b absolute (second order) rate constant of oxidation of 1,2-dichlorobenzene by $\cdot \mathrm{OH},{ }^{c}$ photoelectro-Fenton, ${ }^{\mathrm{d}}$ gas diffusion electrode,

e solar photoelectro-Fenton, ${ }^{\mathrm{f}}$ persulfate, ${ }^{\mathrm{g}}$ electrocoagulation, ${ }^{\mathrm{i}}$ stainless steel 
Table 2. Examples of application of electrochemical technology to treatment of pesticides in soils and groundwater.

\begin{tabular}{|c|c|c|c|c|}
\hline $\begin{array}{l}\text { 1- Target pollutant } \\
\text { 2- Washing solution }\end{array}$ & Process & $\begin{array}{l}\text { Cell configuration } \\
\text { Operating conditions }\end{array}$ & Removal efficiency & Ref. \\
\hline $\begin{array}{l}\text { 1- Atrazine (spiked clay) } \\
\text { 2- Sodium dodecyl sulphate }(100- \\
\left.5000 \mathrm{mg} \mathrm{L}^{-1}\right) \text { and } \mathrm{NaHCO}_{3}(500 \\
\left.\mathrm{mg} \mathrm{L}^{-1}\right)\end{array}$ & $\mathrm{AO}$ & $\begin{array}{l}\text { Continuous circulation }\left(200 \mathrm{~L} \mathrm{~h}^{-1}\right) \text { of the effluent }(1 \mathrm{~L}) \\
\text { in a flow-by cell using BDD anode and steel (diameter }= \\
10 \mathrm{~cm}) . \\
I=30 \mathrm{~mA} \mathrm{~cm}-\end{array}$ & $\begin{array}{l}\text { Complete degradation of atrazine and } \\
\text { sodium dodecyl sulphate and }>90 \% \\
\text { TOC removal at } 30 \mathrm{Ah} \mathrm{L}^{-1} \text {. }\end{array}$ & [36] \\
\hline $\begin{array}{l}\text { 1- Oxyfluorfen (spiked clay) } \\
\text { 2- Sodium dodecyl sulphate }(100- \\
\left.5000 \mathrm{mg} \mathrm{L}^{-1}\right) \text { and } \mathrm{NaHCO}_{3}(500 \\
\left.\mathrm{mg} \mathrm{L}^{-1}\right)\end{array}$ & $\begin{array}{l}\mathrm{AO} \\
\text { and } \\
\text { sono-AO }\end{array}$ & $\begin{array}{l}\text { Continuous circulation }\left(200 \mathrm{~L} \mathrm{~h}^{-1}\right) \text { of the effluent }(1 \mathrm{~L}) \\
\text { in a flow-by cell using BDD anode and steel cathode } \\
\text { (diameter }=10 \mathrm{~cm}) . \\
I=30 \mathrm{~mA} \mathrm{~cm}-2 \\
\text { Auxiliary tank for irradiated experiments }(24 \mathrm{kHz}, 250 \\
\left.\mathrm{W} \mathrm{L} \mathrm{L}^{-1}\right)\end{array}$ & $\begin{array}{l}\text { Complete degradation of oxyfluorfen } \\
\text { at } 25 \mathrm{Ah} \mathrm{L}^{-1} \text { for } \mathrm{AO} \text { and } 40 \mathrm{Ah} \mathrm{L}^{-1} \text { for } \\
\text { sono-AO. } \\
>90 \% \text { TOC removal at } 30 \mathrm{Ah} \mathrm{L}^{-1} \text {. }\end{array}$ & [42] \\
\hline $\begin{array}{l}\text { 1- Lindane (spiked clay soil) } \\
\text { 2- Sodium dodecyl sulphate }(100- \\
\left.5000 \mathrm{mg} \mathrm{L}^{-1}\right) \text { and } \mathrm{NaHCO}_{3}(500 \\
\left.\mathrm{mg} \mathrm{L}^{-1}\right)\end{array}$ & $\mathrm{AO}$ & $\begin{array}{l}\text { Continuous circulation }\left(60 \mathrm{~L} \mathrm{~h}^{-1}\right) \text { of the effluent }(1 \mathrm{~L}) \text { in } \\
\text { a flow-by cell using BDD anode and steel cathode } \\
(\text { diameter }=10 \mathrm{~cm}) . \\
I=50 \mathrm{~mA} \mathrm{~cm}-\end{array}$ & $\begin{array}{l}\text { Complete degradation of lindane at } 15 \\
\text { Ah L } L^{-1} \text { or } 80 \mathrm{Ah} \mathrm{L}^{-1} \text { depending on } \\
\text { extracting agent concentration. }\end{array}$ & {$[43]$} \\
\hline $\begin{array}{l}\text { 1- Clopyralid } \\
\text { 2- Synthetic groundwater }\end{array}$ & $\mathrm{EF}$ & $\begin{array}{l}\text { Batch undivided cylindrical glass reactor }(800 \mathrm{~mL}) \text { with } \\
\text { Pt anode }\left(32 \mathrm{~cm}^{2}\right) \text { and carbon felt cathode }\left(112 \mathrm{~cm}^{2}\right) . \\
\text { Continuous air bubbling. }\left[\mathrm{Fe}^{2+}\right]_{0}=0.1-5 \mathrm{mM} \cdot \mathrm{pH}=3 \\
I=50-300 \mathrm{~mA}\end{array}$ & $\begin{array}{l}80 \% \text { degradation of clopyralid, } 30 \% \\
\text { mineralization and biodegradability } \\
\text { increase after } 480 \text { min of treatment at } \\
200 \mathrm{~mA} \text {. }\end{array}$ & [44] \\
\hline $\begin{array}{l}\text { 1- Phenanthrene (not a pesticide) } \\
\text { 2- Cyclodextrin }\left(9000 \mathrm{mg} \mathrm{L}^{-1}\right)\end{array}$ & $\mathrm{EF}$ and $\mathrm{AO}$ & $\begin{array}{l}\text { Batch undivided cylindrical glass reactor }(400 \mathrm{~mL}) \text { with } \\
\mathrm{Pt} \text {, DSA or BDD anode and carbon felt cathode }(150\end{array}$ & $\begin{array}{l}\text { Complete removal of degradation after } \\
240 \text { min at } 500 \mathrm{~mA} \text { for EF-BDD ( } \mathrm{k}_{\text {app }} \\
\left.=0.012 \mathrm{~min}^{-1}\right) \text { and } 9 \% \text { TOC removal. }\end{array}$ & {$[38]$} \\
\hline
\end{tabular}




\begin{tabular}{|c|c|c|c|c|}
\hline & & $\begin{array}{l}\left.\mathrm{cm}^{2}\right) \cdot\left[\mathrm{Na}_{2} \mathrm{SO}_{4}\right]=0.15 \mathrm{M} \cdot\left[\mathrm{Fe}^{2+}\right]=0.2 \mathrm{mM} \text { and air } \\
\text { bubbling for EF. } \\
I=500-2000 \mathrm{~mA}\end{array}$ & & \\
\hline $\begin{array}{l}\text { 1- Phenanthrene or several PAHs } \\
\text { (not pesticides) } \\
\text { 2- Tween }{ }^{\circledR} 80\left(6550 \mathrm{mg} \mathrm{L}^{-1}\right)\end{array}$ & $\mathrm{AO}$ & $\begin{array}{l}\text { Batch undivided cylindrical glass reactor }(400 \mathrm{~mL}) \text { with } \\
\mathrm{BDD} \text { anode and stainless steel cathode }\left(150 \mathrm{~cm}^{2}\right) . \\
{\left[\mathrm{Na}_{2} \mathrm{SO}_{4}\right]=0.05 \mathrm{M} \text {. }} \\
I=2.1-42 \mathrm{~mA} \mathrm{~cm} \\
\end{array}$ & $\begin{array}{l}\text { Selective degradation of target } \\
\text { pollutants. } 75-90 \% \text { removal of PAHs } \\
\text { after } 23 \mathrm{~h} \text { at } 2.1 \mathrm{~mA} \mathrm{~cm}^{-2} \text {, while the } \\
\text { extraction capacity was only } 5 \% \text { lower } \\
\text { than the fresh one. }\end{array}$ & {$[40 * *]$} \\
\hline
\end{tabular}

